\title{
Article
}

\section{Calculations for treatments for iron deficiency anaemia}

\author{
Nuttall, Dilyse \\ Available at http://clok.uclan.ac.uk/21223/ \\ Nuttall, Dilyse ORCID: 0000-0002-0561-5229 (2016) Calculations for \\ treatments for iron deficiency anaemia. Nurse Prescribing, 14 (7). pp. $326-$ \\ 327. ISSN 2052-2924
}

It is advisable to refer to the publisher's version if you intend to cite from the work. 10.12968/npre.2016.14.7.326

For more information about UCLan's research in this area go to http://www.uclan.ac.uk/researchgroups/ and search for < name of research Group>.

For information about Research generally at UCLan please go to http://www.uclan.ac.uk/research/

All outputs in CLoK are protected by Intellectual Property Rights law, including Copyright law. Copyright, IPR and Moral Rights for the works on this site are retained by the individual authors and/or other copyright owners. Terms and conditions for use of this material are defined in the policies page.

\section{CLoK}

Central Lancashire online Knowledge www.clok.uclan.ac.uk

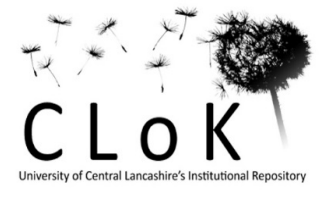




\section{Calculation Skills: Iron Deficiency Anaemia}

NICE (2013) identify iron deficiency as occurring when dietary iron absorption does not sufficiently meet the demand for iron made by the body, resulting in iron deficiency anaemia (IDA) when red blood cell production is reduced as a result. Whilst there may be no signs, even in the event of severe IDA, symptoms include palpitations, fatigue and dyspnoea (NICE, 2013). The first line treatment for IDA should be oral iron tablets alongside dietary advice (NICE, 2013) but any serious underlying causes should be excluded (Joint Formulary Committee, 2016).

Oral iron is given in the form of iron salts. Table 1 shows the iron content of the different iron salts.

\begin{tabular}{|l|l|l|}
\hline \multicolumn{2}{|l|}{ Iron content of different iron salts } \\
\hline Iron salt & Amount & Content of ferrous iron \\
\hline Ferrous fumarate & $200 \mathrm{mg}$ & $65 \mathrm{mg}$ \\
\hline Ferrous gluconate & $300 \mathrm{mg}$ & $35 \mathrm{mg}$ \\
\hline Ferrous sulfate & $300 \mathrm{mg}$ & $60 \mathrm{mg}$ \\
\hline Ferrous sulfate dried & $200 \mathrm{mg}$ & $65 \mathrm{mg}$ \\
\hline
\end{tabular}

Table 1: Source: BNF 71 (JFC, 2016)

\section{$\underline{\text { Question } 1}$}

Based on the figures in the table above, answer the following questions:

(i) How much ferrous iron is in $3.4 \mathrm{~g}$ of ferrous fumarate? Give your answer in grams to one decimal place.

(ii) What percentage of ferrous fumarate is ferrous iron?

(iii) How much Ferrous sulfate (dried) would be needed to provide $292.5 \mathrm{mg}$ of ferrous iron?

(iv) What is the difference (as a percentage) in the ferrous iron content of ferrous gluconate and ferrous sulfate?

\section{Question 2}

After excluding any serious underlying causes of IDA, Raymond is to be prescribed oral iron. Ferrous gluconate is available as $300 \mathrm{mg}$ tablets, at a cost of $£ 3.35$ for 28 tablets. Raymond is to take $1.8 \mathrm{~g}$ daily in divided doses, before food. It is agreed with Raymond that he will split the daily dose between his usual three meals per day.

(i) How many tablets will Raymond take in one week?

(ii) What is the daily cost of treatment (rounded up or down to nearest pence)

\section{$\underline{\text { Question 3 }}$}

Raymond has been unable to tolerate oral iron and so requires an infusion of Iron Dextran, adhering to the following regime: 
$150 \mathrm{mg}$ iron dextran diluted in $500 \mathrm{ml}$ Sodium Chloride, total dose infused over 6hrs $(25 \mathrm{mg}$ to be infused over 15 minutes initially)

(i) How many mls will be infused in the first 15 minutes (rounded up or down to nearest $\mathrm{ml})$ ?

(ii) What dose (in micrograms) will be infused per minute after the initial dose? (Subtract time for initial dose from total infusion time. Round up or down to two decimal places).

\section{Question 4}

Eunice has recently been diagnosed with menorrhagia and is to be prescribed prophylactic ferrous sulfate. Due to swallowing difficulties, she needs to be prescribed oral drops. The price of ferrous sulfate oral drops $125 \mathrm{mg} / \mathrm{ml} 15 \mathrm{ml}$ bottle, is $£ 28.00$. Ferrous sulfate $200 \mathrm{mg}$ tablets cost $£ 1.46$ for 28 tablets.

(i) If Eunice is prescribed a once daily dose of $2.4 \mathrm{mls}$, how much ferrous sulfate will she take daily?

(ii) What is the cost difference between a daily dose of $2.4 \mathrm{mls}$ oral drops and a daily dose of $200 \mathrm{mg}$ tablet ferrous sulfate? (Round costs up or down to nearest pence). 


\section{Answers}

\section{Question 1}

(i) $\quad 3.4 \mathrm{~g}=3400 \mathrm{mg}$

$3400 \div 200=17$

$17 \times 65=1105 \mathrm{mg}$ or $1.1 \mathrm{~g}$

(ii) $100 \%=200 \mathrm{mg} / 1 \%=2 \mathrm{mg}$

$65 \mathrm{mg} \div 2=32.5 \%$

(iii) $292.5 \div 65=4.5$

$4.5 \times 200=900 \mathrm{mg}$

(iv) Ferrous iron content of ferrous gluconate:

$100 \%=300 \mathrm{mg} / 1 \%=3 \mathrm{mg}$

$35 \mathrm{mg} \div 3=11.7 \%$

Ferrous iron content of ferrous sulfate:

$100 \%=300 \mathrm{mg} / 1 \%=3 \mathrm{mg}$

$60 \div 3=20 \%$

Difference $=20-11.7=8.3 \%$

\section{Question 2}

(i) Daily dose $=1.8 \mathrm{mg}=6 \times 300 \mathrm{mg}$ tablets

Weekly $7 \times 6=42$ tablets

(ii) $\quad £ 3.35=335 p$

Cost of 1 tablet $=335 \div 28=12 p$ (rounded up)

Daily cost $=12 p \times 6=72 p$

Question 3

(i) $500 \mathrm{ml}=150 \mathrm{mg}$

$1 \mathrm{ml}=0.3 \mathrm{mg}$

$25 \mathrm{mg} \div 0.3=83 \mathrm{ml}$ (rounded down)

(ii) Remaining time $=5 \mathrm{hrs} 45$ mins $=345$ minutes

Remaining amount of drug $125 \mathrm{mg}$

$125 \div 345=0.36 \mathrm{mg}=360$ micrograms (rounded down)

\section{Question 4}

(i) $125 \times 2.4=300 \mathrm{mg}$ 
(ii) Oral drops:

Daily cost $=£ 28 \div 15 \times 2.4=£ 4.48$

Tablets:

Daily cost $=£ 1.46 \div 28=5 p$ (rounded down)

Cost difference $=£ 4.48-5 p=£ 4.43$

\section{References}

*Joint Formulary Committee (2016) British National Formulary 71 (March 2016), London: BMA \& RPSGB

NICE (2013) Anaemia: Iron Deficiency. Online at http://cks.nice.org.uk/anaemia-irondeficiency 